\title{
Rhetorical Analysis on Expectations and Functions in Jawaharlal Nehru's Eulogy for Mahatma Gandhi
}

Kangsheng Lai*

Pingxiang University, China

Corresponding Author: Kangsheng Lai, E-mail: andytuguegarao@gmail.com

\section{ARTICLE INFO}

Article history

Received: October 04, 2018

Accepted: December 12, 2018

Published: February 28, 2019

Volume: 10 Issue: 1

Advance access: January 2019

Conflicts of interest: None

Funding: None

Key words:

Eulogy,

Mahatma Gandhi,

Jawaharlal Nehru,

Expectation,

Function

\begin{abstract}
The paper introduces the life story of Mahatma Gandhi and Jawaharlal Nehru and then analyzes the relationship between the two great people in India. After Gandhi's death, Jawaharlal Nehru delivered the eulogy for commemorating his intimate comrade and respectful mentor Mahatma Gandhi, the Father of India. Under generic constraints based on audience's expectation and need, the eulogy is analyzed from the perspectives of two major expectations and five basic functions. Through the rhetorical analysis of Jawaharlal Nehru's eulogy, it can be concluded that a good eulogy should meet audiences' two major expectations and five basic functions.
\end{abstract}

\section{INTRODUCTION}

\section{Life Story of Mahatma Gandhi}

Mahatma Gandhi was born on October 2, 1869. He was an activist in India who struggled for the independence from the British rule all his life. Movements for civil rights and freedom all over the world were inspired by his advocation of nonviolent civil disobedience. Indian people would like to call him the Father of the Nation.

Born in a Hindu merchant family, Gandhi spent his childhood in coastal Gujarat, India, and learned law in London in his youth. As an expatriate lawyer in South Africa, he firstly advocated nonviolent civil disobedience to struggle for civil rights in the resident Indian community. In 1915 when he returned to his motherland, he launched movements against excessive land-tax and discrimination. In 1921, he was elected as the leader of the Indian National Congress and organized people to struggle for independent rule.

A new Muslim nationalism, endeavoring to establish a Muslim separated from India, posed a great challenge to Gandhi's idea of an independent multi-religious country in the early 1940s. In August 1947, India was independent from Britain finally. However, the country had been separated into two parts. One was a Hindu-majority India and the other was
Muslim-majority Pakistan. Religious violence took place in the Punjab and Bengal because of the substitution of Hindus, Muslims, and Sikhs decided on setting up their own land. Gandhi paid a visit to the places where religious violence broke out, intending to give the affected people solacement while he had planned to present the official celebration of independence in Delhi. He went on a hunger strike to prevent the possibly proceeding religious violence. He put pressure on Indian government to provide financial support for Pakistan when he was 78, on January 12, 1948. Nathuram Godse, a millitant and Hindu extremist who thought Gandhi was too accommodating, assassinated him on January 30,1948 . In the purpose of commemorating their beloved leader, they granted his birthday, October 2, as the International Day of Nonviolence celebrated all over the world (Richard Deats, 2005).

Indians can take great pride in the fact that many well-known personalities cite Mahatma Gandhi as their role model and give an extremely high appraisal to him. Nelson Mandela is the "Gandhi" of South Africa and he regarded Gandhi as his great mentor: "Gandhi made a great contribution to South Africa's transformation and without Gandhi's preaching, we could have not abolished apartheid." "Christ gave us the goals and Mahatma Gandhi the tactics," said Martin Luther King Jr., 
who appealled African Americans to struggle for their rights by using non-violence as the weapon. Albert Einstein enjoyed a deep friendship with Gandhi. They admired each other and often communicated by writing letters. In Einstein's letter to Gandhi, he thought Gandhi as "a role model for the generations to come". Former US Vice-President and environmentalist Al Gore had been profoundly influenced by Gandhi in his solving green house effect. He thought that Mahatma Gandhi's non-violence gave him the power of truth to encourage him to fight for the global warming persistently. Rabindranath Tagore, sharply different from the philosophy of Gandhi, is the first one who called Mohandas Karamchand Gandhi as Mahatma Gandhi (Nishi Malhotra, 2015).

\section{Life Story of Jawaharlal Nehru}

Pt. Jawaharlal Nehru was born on November 14, 1889. He fighted for freedom for a lifelong time. No matter before or after independence, he was the most important person in Indian politics and he was the first Prime Minister after independence. Led by Mahatma Gandhi, he fighted for independence from British control along with his mentor. $\mathrm{He}$ was elected as the first Prime Minister in 1947 when India was independent. He was entitled as the forefather of modern India by people all over the world. Owing to his rooted relationship with the Kashmiri Pandit community, He was also considered as Pandit Nehru while he was called Chacha Nehru by Indian children (Gopal Sarvepalli, 1984).

Motilal Nehru was the father of Nehru and his father was an outstanding lawyer and nationalist statesman. After graduation from Trinity College, Cambridge, he was trained to be a barrister. When he went back to India, he worked at the Allahabad High Court but eventually he gave up his legal practice due to his interest in national politics. Since he was a teenage, he was a committed nationalist and played a vital role in the upheavals of the 1910s. With the tacit approval of his mentor, Gandhi during the 1920s, the Indian Congress elected him as the president of the left-wing factions.

As India moved towards independence, Nehru was the central figure in Indian politics during the 1930s. The Congress chose him as the independent India's first Prime Minister. As a matter of fact, he was acknowledged as Gandhi's political heir and successor dated back to 1941 . Indian people still regarded Nehru as their beloved first leader of independent India although he was involved in the political troubles in his latter leadership and lost the battle with China in 1962. His birthday, November 14, is celebrated as Children' Day in India.

\section{RELATIONSHIP BETWEEN JAWAHARLAL NEHRU AND MAHATMA GANDHI}

Although Gandhi was different from Pt. Jawaharlal Nehru in respect of philosophy of life, society and politics and in regard to the shape of social economic and political structure of Indian polity after Independence, the two leaders lived and worked harmoniously during the struggle for freedom during 1919 - 1947 and Nehru was always the firm follower of Mahatma Gandhi.
He was willing to follow the Great Mahatma, even when he failed to understand his logic, because Pt. Nehru knew that Gandhi knew the secret and could wield the mysterious power (Suraj Kapoor, 1994). His loyalty to Gandhi was true and tested, and Gandhi's love for him was deep and abiding.

Neither Nehru nor Gandhi would have made such a great contribution to Indian independence without each other. The two understood each other. This understanding was a measure of Gandhi's greatness and of Nehru's wisdom. Nehru was Gandhi's ears and eyes and acknowledged as Gandhi's successor in 1941. Gandhi selected Nehru as his political heir because he hoped when he was dead, Nehru would speak the language of Gandhi.

After Gandhi was dead, his best friend and comrade, Jawaharlal Nehru wrote a eulogy and broadcast it on the radio in public to commemorate Mahatma Gandhi. In the eulogy, Nehru thought highly of Gandhi and expressed sincerely his appreciation and admiration as to Gandhi's great contribution to the freedom and independence of India. The eulogy is a classic works with various rhetorical devices used in it. Audiences' expectation from the eulogy and the eulogy's five basic functions will be analyzed in the following parts.

\section{RHETORICAL ANALYSIS ON JAWAHARLAL NEHRU'S EULOGY FOR MAHATMA GANDHI}

\section{Analysis on Kategoria in the Eulogy}

A eulogy is presented on one's funeral service to praise his or her contribution that he or she made before he or she was dead. Except expressing eulogy orator's appreciation and respect for the decreased, eulogy can also be functioned as a tool to console his or her followers and make a defense for the ill-treatment from his or her opponents.

Eulogy is regarded as an important part of funeral services. However, to maintain respect for traditions, Eulogies are either discouraged or not allowed at the funeral service of some religious factions. On the funeral service, the orator usually delivered the eulogy to express his or her respect or appreciation of the deceased. Apart from eulogies for the dead, they are also presented on special occasions like birthdays, office parties, retirement celebrations, etc. Eulogy is different from elegy. Eulogy is in the form of speech while elegy is in the form of poem written in tribute to the dead; it is also different from obituary. Obituary is biography written about the life story of the deceased; it is also different from obsequy, which is the ritual held for the deceased.

Oratory does not always consist of single type of rhetorical genres. It is always combined with different rhetorical forms, which is called "rhetorical hybrids." Rhetorical hybrids are defined as combination of the various rhetorical genres. According to Aristotle's classification of rhetorical forms based on the persuasive aspect of rhetoric, rhetorical hybrids are the fusions of judicial rhetoric, demonstrative rhetoric, and deliberative rhetoric. There are three genres of rhetoric: eulogies, kategoria and apologia. The term "kategoria" was a noun signifying an accusation or charge (David K. Scott, 1998). Kategoria belongs to judicial rhetoric which was used in the courts to prove or disprove the guilt of the 
accused person while funeral eulogy belongs to the demonstrative rhetoric which is used to show the orator's respect or disrespect for someone on a particular occasion, such as funeral service. Jamieson and Campbell (1982) argue that the incorporation of multiple genres can only be "functional" if they are subordinate to the primary functions and expectations of one genre. As far as a eulogy is concerned, a "functional hybrid" will take place when it is regarded as a ritual to commemorate the deceased, when it is in accord with positions advocated by the orator of eulogies, whose motivation should not be selfish, and when the audience or community will not be divided by the eulogists' affirmation.

The eulogy is made by Jawaharlal Nehru to commemorate the humble life that Mahatma Gandhi lived, honoring him one last time. Jawaharlal Nehru made the funeral speech when he served as the first Prime Minister of India after the independence. The eulogy is presented over radio a few days after assassination of Gandhi on 30 January 1948. He was assassinated by Nathuram Vinayak Godse, who was a member of right-wing faction advocating Hindu nationalism. He was also a member of the political party the Hindu Mahasabha. The assassination was planned by Godse, for he thought that during the partition of India, Gandhi met the political demands which were asked by India's Muslims. In Nehru's funeral oration, he accused his assassination, “... Yet ultimately things happened which no doubt made him suffer tremendously, though his tender face never lost its smile and he never spoke a harsh word to anyone... the hand of a child of his struck him down." (Jawaharlal Nehru, 1948).

Jewaharlal Nehru accused the assassination of Nathuram Vinayak Godse harshly by using these sentences. These sentences are the example of genre of kategoria which had been fused into Nehru's eulogy. Although most part of the eulogy was delivered to express Jewaharlal Nehru and Indian people's grief and respect for Mahatma Gandhi, the orator had not forgotten to make a strong accusation for the crime committed to their beloved leader.

\section{Analysis on the Expectations and Functions in the Eulogy}

Eulogies typically operate under generic constraints based on audience expectation. Brownlow and Davis (1974) identified audience's two main expectations: (1) express eulogist and audience's sadness about the deceased; (2) to show respect and appreciation for the dead. Eulogy is used as a form of rhetoric to confirm the worth of the deceased. Jamieson (1978) put forward five basic functions of eulogies on the basis of audience need: (1) to make the shocked audience believe in the reality of death; (2) to reveal the truth that nobody is immortal; (3) to alter the relationship between the people alive and the person who is dead by changing the present tense to past tense; (4) attempt to console the audience by arguing that the deceased "live on" in everyone's memory; (5) reiterate a sense of community identity.

The five-mile long funeral procession from Birla House to Raj Ghat took the people who joined in the procession more than five hours. On the funeral service of Gandhi, Prime Minister of India, Jawaharlal Nehru made the funeral speech for people to mourn their beloved Gandhi, the Father of the Nation.

Nehru expressed appropriate personal and audience grief at the beginning of his eulogy. "A glory has departed and the sun that warmed and brightened our lives has set, and we shiver in the cold and dark." (Jawaharlal Nehru, 1948) In this sentence, Nehru compared the death of Gandhi to the sunset. When sun has set, there is no warm any more and we are living in the dark. This situation is just like the death of Gandhi. When Gandhi was dead, Indian people felt they were living in the cold and dark. The brightness and warmness brought by Gandhi had disappeared forever. The metaphor used in the sentence vividly conveys the people's grief when they lost such a respectful leader.

The Prime Minister generously offered his words of praise to deepen appreciation and respect for Gandhi. "After all, that glory that we saw for all these years, that man with divine fire, changed us also--and such as we are, we have been molded by him during these years. " (Jawaharlal Nehru, 1948) As a matter of fact, there are many sentences in the eulogy for expressing their appreciation and respect for Gandhi, but the above sentence typically depicted Gandhi's deep and profound influence on his supporters.

Jawaharlal Nehru spoke the following words in the purpose of establishing the reality of death to a disbelieving audience. "He has gone, and all over India there is a feeling of having been left desolate and forlorn." (Jawaharlal Nehru, 1948) People in India were shocked at the assassination of Gandhi. They couldn't accept the reality that their beloved leader was gone in this way. They were soaked in extreme sadness and outrage. They felt sad because they lost such a great leader; they felt outrage because the killer was Gandhi's previous follower. When Nehru delivered the eulogy, he knew it's necessary to tell the audience that Gandhi was passed away indeed.

The Prime Minister Nehru helped the audience deal with their own sense of mortality indirectly by using the following words. "In ages to come, centuries and maybe millennia after us, people will think of this generation when this man of God trod on earth, and will think of us who, however small, could also follow his path and tread the holy ground where his feet had been." (Jawaharlal Nehru, 1948) In the eulogy, Nehru didn't help the audience accept the reality of mortality directly. In his eulogy, he said: “.... and will think of us who, however small, could also follow his path and tread the holy ground where his feet had been." among which "follow his path", "his feet had been" indicate that nobody is immortal and we are all passers-by in the long history.

The Prime Minister tried to change the relationship between the living and the dead from present to past tense. "And if those living flames exist, there will not be darkness in this land, and we shall be able, with our effort, remembering him and following his path, to illumine this land again, small as we are, but still with the fire that he instilled into us." (Jawaharlal Nehru, 1948) The relationship between the living and the dead was demonstrated through the change of tense from present to past. Present tense is used in the sentence "small as we are, but still with the 
fire" to show that they were ordinary people but Gandhi endowed them with power, which is symbolized by the "fire". Past tense is used in the sentence "he instilled into us" to show that the dead exerted great influence on the living.

Jawaharlal Nehru attempted to console the audience by arguing that the deceased "live on" in everyone's memory. "He lives in the hearts of millions and he will live for immemorial ages." (Jawaharlal Nehru, 1948) Another function of eulogy is to console the audience. Nehru just told his audience that nobody is immortal which means the flesh will disappear one day but their spirit will live on permanently. "he will live for immemorial ages" provides the evidence to prove this point.

The Prime Minister Nehru reaffirmed a sense of identity for the community by saying that Gandhi was "perhaps the greatest symbol of India of the past, and may I say, of the India of the future, that we could have had." (Jawaharlal Nehru, 1948) Here, Nehru emphasized the importance of Gandhi to India again. He fully affirmed Gandhi's position in the history of India.

There are many other examples in Nehru's eulogy which can be listed here to provide more evidence to approve that his eulogy successfully met the generic constraints and expectation. The above examples are so typical that it is unnecessary to analyze others. Eulogy, as a special type of speech, is operated based on the audience's two major expectations and five basic functions. The orator of the funeral speech should bear these in mind and write his or her eulogy including the two expectation and five functions. Only in this way, can his or her eulogy be considered as a successful speech in the funeral service.

\section{CONCLUSION}

Mahatma Gandhi is the leader of nonviolent movement against British rule over India. Since he had made a great contribution to the independence of India, he is universally known as "Mahatma Gandhi" but not his real name "Mohandas Karamchand Gandhi". "Mahatma" means "great soul" which means Gandhi is an Indian activist with great soul. Jawaharlal Nehru is the first Prime Minister of India after independence from Britain. They participated in the struggle for independence for the country and Gandhi is believed to be the mentor of Nehru. Although they differed very much in their ideologies and lifestyle, they had a solid relationship with each other. Upon Gandhi's death, Nehru delivered the eulogy over the national radio on his funeral service. In his eulogy, he expressed his personal grief about losing a comrade. In the meantime, he also granted Indian people to mourn their beloved leader.

Nehru delivered the funeral speech under generic constraints fully based on audience's expectation and need. He talked about Gandhi's death to convey their desperate sadness. The contribution and achievements made by Gandhi were mentioned in his eulogy to express their appreciation and respect for the deceased. He made the shocked people to accept the reality that Gandhi had passed away indeed. He sought to persuade audience to believe that everybody would die one day even the greatest men. The flesh of the greatest men will disappear forever one day, but their spirit will live on permanently over the world. Nehru's eulogy completely meets with audience's expectation and need. It is the typical example of rhetorical hybrids fused with both the functions of eulogy and kategoria. It is considered to be a classic work among other eulogies for Mahatma Gandhi.

\section{REFERENCES}

Brownlow, P.C. \& Davis, B. (1974). "A certainty of honor": The eulogies of Adlai Stevenson. Central States Speech Journal, 25, 217-224.

David K. Scott. (1998). Diana's Eulogy: Breaking New Ground in Epideictic Rhetoric? Annual Central States Communication Association Meeting in Chicago, Illinois, April 2-5.

Gopal Sarvepalli. (1984). Jawaharlal Nehru: a biography. Harvard University Press.

Jamieson, K.H. \& Campbell, K.K. (1982). Rhetorical hybrids: Fusion of generic elements. In S.K. Foss (Ed.) Rhetorical criticism. Prospect Heights, IL: Waveland. pp. 135-148.

Richard D. (2005). Mahatma Gandhi: Nonviolent Leader. NY: New City.

Suraj, K., Janet, B. (1994). Polarization of Indian Press During Nehru-Gandhi Dynasty. World Communication.

Jawaharlal, N. (1948). Eulogy for Mahatma Gandhi. [Online]. Available: http://www.kamat.com/mmgandhi/eulogy.htm (Feb. 2, 1948).

Nishi, M. (2015) 20 Greatest World Leaders and Thinkers Who were Inspired by Mahatma Gandhi. [Online]. Available: https://www.thebetterindia.com/35422/20-greatestworld-leaders-and-thinkers-who-were-inspired-by-mahatma-gandhi/(October 2, 2015). 